\title{
Science - Sense of Life
}

\section{Dear readers,}

European Financial and Accounting Journal boasts about attribute "scientific". Therefore let me put a question whether people thirst for science. Most of us probably answered yes. From medical sciences we expect new remedies for old and new diseases, from technical research we hope for new inventions which will make our labor and personal life more pleasant, inquiry of agriculturalists could save humanity from hunger and knowledge of natural sciences from catastrophic consequences of global warming. However what people expect from social sciences especially from economic sciences? We must admit that most people expect just nothing from our research whatsoever. One time I wanted to show off in front of my friends from medical environment that the University of Economics in Prague and especially our Faculty of Finance and Accounting will hold a giant European congress ${ }^{1}$ for more than one thousand accounting scientists from all over the world. Then I received a very amused smile upon image what so many accountants want to inquire. According to thoughts of many persons especially politicians everything in economic science has been long time ago already discovered. However, also other scientific disciplines were confronted with similar prejudices in the past.

Thesis "everything that can be invented has been invented" belongs to favorite quotations on the internet. This pronouncement is attributed to ${ }^{2}$ Charles H. Duell who supposed to use it in 1899, when as a director of the U.S. Patent Office sent a report to William McKinley, the president of the USA. In other words he might have suggested an abolishment of his office and consequently also his post of a director. Fortunately, American archives attentively treasure all official correspondence of presidents, and

$27^{\text {th }}$ Annual Congress of the European Accounting Association was held by the University of Economics, Prague from $1^{\text {st }}$ to $3^{\text {rd }}$ April, 2004 with participation of more than 1200 delegates from 50 countries.

2 See Morgan, C. - Langford, M.: The Book of Facts and Fallacie. New York, St. Martin's Press, 1981, or Cerf, S. - Navasky, V.: The Expert Speak. New York, Pantheon, 1984. 
inquirers have been successful ${ }^{3}$ in searching for this original report. It has not contained such a monstrous sentence, quite the contrary C. H. Duell argued that "our future progress and prosperity depend upon our ability, to equal, if not surpass, other nations in the enlargement and advance of science, industry and commerce", and insisted on the president of the USA for most powerful support which could lead to new discoveries and new inventions.

American film-makers tried attributing this thesis to another scientist in the film of Around the World in 80 Days. ${ }^{4}$ This victim became an English inventor Lord Kelvin of Largs, original name William Thomson. In the film he represented the main baddy man who was in permanent opposition against any progress. In fact, he was a very reputable scientist who wrote over six hundred scientific publications and filed around seventy patents. As a physicist he dealt for example with thermodynamics and later the unit of temperature measure was named in memory of him. His greatest success represents his credit of his work on the transatlantic telegraph cable laying project which has brought him a noble title at the age of 42 years. Opposite to perception and "deep historical knowledge" of American screenwriters he proclaimed in public that "one thing we may prophesy of the future for certain - it will be unlike the past. Everything is in a state of evolution and progress". 6

Disparagement of famous scientists against other scientific disciplines of other branches is broadly known. The relation is nicely sketched in a statement which was declared by Lord Ernest Rutherford of Nelson, the founder of nuclear physics theory based on which "all science is either physics or stamp collecting"7. However, it is necessary to admit that economic science has many common aspects with stamp collecting. In the

3 See Sass, S.: A Patently False Patent Myth. Skeptical Inquirer, 1989, vol. 13, no. 3, pp. 310-313.

4 Film of Around the World in 80 Days was made in 2004 by director Frank Coraci, the role of Lord of Kelvin was performed by Jim Broadbent.

5 In their excuse it is necessary to notice that Lord of Kelvin distinguished himself several times by bad predictions. For example in 1896 he originally declared X-ray as a hoax, however after Röntgen had submitted his scientific evidence, he acknowledged his mistake. In 1902 in an interview for Newark Advocate $\left(26^{\text {th }}\right.$ April, 1902) he expressed his opinion that "no balloon and no aeroplane will ever be practically successful".

6 Lord of Kelvin: An Address at the Annual Meeting of the Christian Evidence Society. $23^{\text {rd }}$ May, 1889.

7 Cited in Birk, J. B.: Rutherford at Manchester. London, Heywood, 1962. 
PREFACE - Marek, P.: Science - the Sense of Life.

same way as philatelists collect stamps, we collect data, as well as philatelists sort stamps according to certain topics, we sort data according to certain aspects and also as philatelists present their collection on international exhibitions, we present our scientific contributions on international conferences. With philatelists we have similar enthusiasm. However, let me claim that our mission is most useful than only stamp collecting.

Nevertheless, our science correspond more than other sciences to the above cited proclamation of Lord of Kelvin, yet our research is able to discover new pieces of knowledge and bring new methods which can help for example remove financial crisis causes. And this is the main reason why we regard our science as sense of life. And it is also the main reason why we issue our scientific journal.

prof. Ing. Petr Marek, CSc.

Editorial board's chairman European Financial and Accounting Journal

and investigator of the research plan

Development of Financial and Accounting Theory and its Application in Practice from Interdisciplinary Point of View 